\title{
KEMAMPUAN PEMECAHAN MASALAH MATEMATIKA SISWA KELAS VIII-A SMPK ST. PAULUS KARUNI PADA MATERI GEOMETRI
}

\author{
Grassiana Misseri Cordia \\ Fakultas Keguruan dan Ilmu Pendidikan Universitas Sanata Dharma, Yogyakarta \\ grassianamissericordia@gmail.com
}

\begin{abstract}
Abstrak
Penelitian ini bertujuan untuk menganalisis kemampuan pemecahan masalah siswa kelas VIII SMPK St. Paulus Karuni pada materi persegi dan persegi panjang dengan menggunakan model pembelajaran berbasis masalah (PBM). Penelitian ini merupakan penelitian deskriptif kualitatif dimana hasil penelitian digambarkan dengan menggunakan penjelasan-penjelasan yang ilmiah. Teknik pengumpulan data dalam penelitian ini berupa analisis hasil kerja siswa, tes, observasi kemampuan siswa dalam menyelesaikan latihan dan wawancara. Latihan yang diberikan kepada siswa sesuai dengan masalah yang sering dijumpai siswa dalam kehidupan sehari-hari. Analisis kemampuan pemecahan masalah siswa menggunakan indikator kemampuan pemecahan masalah dari Polya. Peneliti melakukan pembelajaran sesuai dengan langkah-langkah pembelajaran berbasis masalah. Berdasarkan hasil observasi pembelajaran dengan menggunakan langkah-langkah dari Polya disimpulkan bahwa penerapan model Pembelajaran Berbasis Masalah (PBM) dapat meningkatkan kemampuan pemecahan masalah matematika siswa pada materi bangun datar di Kelas VIII SMPK St. Paulus Karuni. Hal ini terlihat ketika dalam menyelesaikan masalah yang diberikan oleh peneliti, siswa memahami masalah kemudian membuat rencana untuk menyelesaikan latihan serta melaksanakan rencana dan menuliskan jawabannya langkah demi langkah dengan menggunakan model matematika yang sesuai. Selain itu siswa dapat menjelaskan jawaban dengan alasan yang sesuai. Namun banyak juga siswa yang tidak memenuhi indikator keempat yakni melihat kembali jawabannya.
\end{abstract}

Kata Kunci: Pemecahan Masalah, Model PBM

\begin{abstract}
This study aims to analyze the problem-solving abilities of the VIII grade students of SMPK St. Paulus Karuni on square and rectangular material using a problem-based learning model (PBL). This research is a qualitative descriptive study where the research results are described by scientific explanation. Data collection techniques in this study were in the form of analysis of student work results, tests, observation of students' abilities in solving practice questions and interviews. The exercises given to students are in accordance with the problems that students often face in everyday life. Analysis of student problems using indicators of mathematical problem solving abilities according to Polya. Researchers carry out learning in accordance with problem-based learning steps. Based on learning observations using steps from Polya, it is neglected that the application of the Problem Based Learning (PBL) model can improve students' mathematical problem management skills on flat form material in class VIII SMPK St. Paul Karuni. This can be seen when solving the problems given by the researcher, students understand the problem then plan to solve the practice questions and carry out the plans and answers step by step using the appropriate mathematical model. In addition, students can explain answers with appropriate reasons. However, many students who did not meet the fourth indicator looked back at their answers.
\end{abstract}

Keywords :Problem Solving, Problem Based Learning

\section{PENDAHULUAN}

Pendidikan matematika pada abad 21 menekankan pada berpikir kritis dan pemecahan masalah (critical thinking and problem solving), kreatif dan inovatif (creativity and innovation), komunikasi, dan kolaborasi (Mulyana: 2017). Berbagai upaya telah dilakukan oleh pemerintah untuk memenuhi tuntutan tersebut yakni menyelenggarakan pendidikan dengan membuat program pendampingan bagi para guru melalui Pendidikan Profesi Guru (PPG), meningkatkan dan memperbaiki kualitas pengajaran melalui 
seminar tentang pedidikan dan memperkenalkan beberapa metode ajar serta membuat temuan-temuan baru untuk mempermudah pemahaman siswa terhadap materi yang diajarkan. Selain itu guru dituntut untuk membuat Rencana Pelaksanaan Pembelajaran (RPP) terkait materi yang akan diajarkan sehingga menjadi lebih jelas apa yang akan diajarkan karena materi ini telah dipersiapkan sebelumnya. Latihanlatihan yang dirancang diharapkan sesuai dengan kebutuhan siswa saat ini yakni menyelesaikan masalah yang terkait erat dengan kehidupan siswa.

Dalam membuat RPP guru perlu mempertimbangkan kesesuian antara metode pembelajaran, materi ajar dengan kondisi siswa. Demikian juga dengan proses pembelajaran matematika. Proses itu harus dirancang sedemikian rupa sehingga siswa belajar menemukan sendiri baik ide-ide dasar maupun konsep serta dapat memecahkan masalah matematika. Sebagai seorang guru dan pendidik kita ditantang untuk menciptakan proses pembelajaran yang kreatif dan melibatkan proses berpikir kritis karena dengan berpikir kritis mampu menggali informasi yang telah tertanam sebelumnya dari pemikiran siswa sehingga siswa benar-benar mengalami proses belajar.

Namun hal tersebut tidak sesuai dengan kenyataan yang ditemukan oleh peneliti. Berdasarkan hasil observasi yang dilakukan oleh peneliti pada tanggal 29 Maret 2019 pada siswa kelas 8 SMPK st. Paulus Karuni, guru masih menggunakan metode konvensional yakni guru menjelaskan materi kemudian menuliskan rumus yang terdapat dalam buku di papan tulis dan meminta siswa untuk mengerjakan latihan sesuai dengan rumus atau pola yang dibuat oleh guru. Dengan demikian siswa malas untuk berpikir karena merasa bahwa latihan ini tidak terlalu menantang dan sudah diberikan contoh sebelumnya. Selaras dengan penelitian lainnya mengemukakan bahwa guru sering memaksa siswa untuk mengerjakan latihan dengan pola yang terdapat pada buku dan meminta siswa untuk menghafal rumus sehingga siswa cenderung membenci pelajaran matematika (Marpaung dalam Fauzan: 2017).Sehingga memberikan dampak bahwa pengetahuan yang diperoleh siswa kurang bermakna dan cepat terlupakan (Fauzan, 2002).

Sebagian besar siswa mengalami kesulitan dalam memahami konsep-konsep matematika yang mereka pelajari, karena apa yang dipelajari bersifat abstrak dan siswa tidak dilatih untuk berpikir kritis. Kebanyakan guru hanya mengatakan "benar" jika jawaban yang diberikan oleh siswa benar dan "salah" jika jawaban yang diberikan oleh siswa salah tanpa bertanya lebih lanjut mengapa kamu memberikan jawaban seperti itu. Selain itu, apabila guru membuat kesalahan dalam pengajaran siswa tidak dapat memberikan komentar karena siswa berpikir bahwa apa yang dibuat oleh guru sudah benar.

Pendekatan pembelajaran yang digunakan dan buku-buku teks matematika masih belum memberi kesempatan yang cukup kepada siswa untuk belajar matematika, melainkan untuk mengingat matematika (Fauzan, A dan Oci: 2017). Untuk itu diperlukan suatu pendekatan pembelajaran yang melibatkan guru dan siswa untuk berpikir kritis dalam menyelesaikan masalah matematika. Guru perlu menyiapkan latihan yang memungkinkan siswa untuk menggali ide-ide matematika dan dapat merangsang siswa untuk berpikir menemukan sendiri solusi dari masalah tersebut. Pemberian masalah dimaksudkan untuk mengikat siswa pada rasa ingin tahu terhadap materi pembelajaran.

Materi geometri lebih khususnya segi empat merupakan materi yang terdapat dalam pembelajaran matematika. Masalah geometri merupakan masalah yang real dalam kehidupan siswa dimana kegiatan menghitung, mengukur, mendesain dan merepresentasikan bentuk yang konkrit ke dalam bentuk yang abstrak. Materi geometri sampai saat ini masih dianggap sulit oleh sebagian siswa kelas 8A SMPKSt. Paulus Karuni karena saat peneliti memberikan latihan yang berkaitan dengan soal cerita yang terdapat dalam kehidupan siswa, siswa sulit mengaplikasikan materi yang sudah diperoleh untuk menyelesaikan masalah matematika. Saat ditanya tentang rumus untuk menentukan luas dan keliling dari bangun datar persegi dan persegi panjang, siswa dengan cepat menyebutkan rumus dari kedua bangun datar itu baik menentukan luas maupun keliling dari segiempat. Banyak latihanyang terdapat dalam buku sekolah 
Indonesia hanya mencantumkan panjang, lebar suatu bangun datar dan langsung meminta siswa untuk menghitung luas maupun keliling dari bangun tersebut. Namun untuk soal aplikasi dalam kehidupan sehari-hari masih terasa sulit. Pembelajaran berbasis masalah merupakan sebuah model pembelajaran yang menyajikan masalah kontekstual sehingga merangsang siswa untuk belajar (As'ari., dkk: 2017).

Dalam penelitian ini, peneliti melaksanakan pembelajaran dengan menggunakan model pembelajaran berbasis masalah. Langkah-langkah pembelajaran berbasis masalah menurut As'ari., dkk adalah sebagai berikut: a) Orientasi siswa pada masalah. Hal ini meliputi: guru mengawali kegiatan pembelajaran dengan menjelaskan tujuan pembelajaran, memotivasi siswa untuk terlibat aktif dalam pemecahan masalah yang dipilih; b) mengorganisasikan siswa; c) membimbing penyelidikan individu dan kelompok d) mengembangkan dan menyajikan hasil karya ; dan e) menganalisis dan mengevaluasi pemecahan masalah. Dalam penelitian ini, peneliti merancang pengajaran dan melaksanakan pengajaran sesuai dengan model pembelajaran berbasis masalah. Jawaban-jawaban yang diberikan oleh siswa akan dianalisis dengan menggunakan langkah-langkah pemecahan masalah dari Polya. Adapun langkahlangkah pemecahan masalah menurut Polya (1973: xvi), yakni: 1) Memahami masalah (understanding the problem), 2) Merancang rencana penyelesaian (devising a plan), 3) Melaksanakan rencana penyelesaian (carrying out the plan), dan 4) Melihat kembali langkah penyelesaian (looking back).

\section{METODE}

Subjek dalam penelitian ini adalah seluruh siswa kelas 8A SMPK St. Paulus Karuni yang berjumlah 10 orang. Penelitian ini dilaksanakan pada bulan Maret 2019. Penelitian ini merupakan penelitian deskriptif kualitatif. Menurut Best (dalam Sukardi, 2003:157), penelitian deskriptif merupakan metode penelitian yang berusaha mengambarkan dan menginterprestasikan objek sesuai dengan apa adanya. Data yang diperolah dalam penelitian ini adalah data kualitatif. Kemudian data tersebut dianalisis menggunakan indikator kemampuan pemecahan masalah matematika menurut Polya. Dalam penelitian ini, peneliti mendeskripsikan tentang kemampuan siswa dalam menyelesaikan masalah yang berkaitan dengan soal cerita pada materi persegi dan persegi panjang. Wawancara dilakukan oleh peneliti pada saat siswa menyelesaikan latihan. diperlukan untuk mendapatkan penjelasan dari jawaban yang dituliskan oleh siswa pada lember kerja siswa. Penjelasan yang diperoleh digunakan untuk membuat kesimpulan dan menjawab pertanyaan penelitian.

\section{HASIL PENELITIAN DAN PEMBAHASAN}

Berdasarkan data yang dikumpulkan oleh peneliti maka peneliti memutuskan untuk menganalisis hanya beberapa jawaban dari siswa karena dari jawaban yang ditemukan oleh peneliti terdapat beberapa orang siswa memiliki jawaban yang sama. Untuk itu, peneliti menganalisis berdasarkan jawaban yang hanya mengacu pada kesalahan umum yang dibuat oleh siswa. berikut:

Hasil analisis terhadap jawaban siswa pada materi persegi dan persegi panjang adalah sebagai

A. Analisis kemampuan pemecahan masalah siswauntuk soal bagian a.

\section{Soal}

Ibu Elisa memiliki taman seperti pada gambar berikut. 
Di sekeliling taman tersebut dipasang pagar dengan biaya Rp. 12.000 per meter. Seluruh

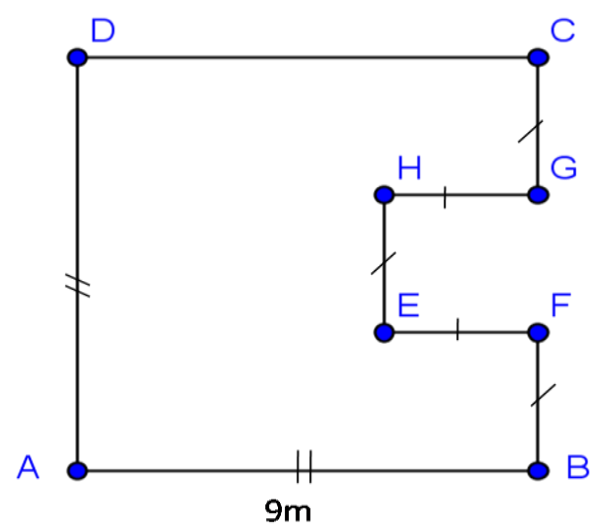

Gambar 1.1 Dena Rumah Ibu Elisa

permukaan taman ditanami rumput dengan biaya Rp. 10.000 per $\mathrm{m}^{2}$.

Hitunglah:

a. Biaya pemasangan pagar

b. Biaya penanaman rumput

Berdasarkan scan hasil kerja siswa untuk latihan bagian a, peneliti menemukan 3 jenis jawaban yang berbeda dari siswa.

1. Jenis Jawaban Pertama

Pada jenis jawaban yang pertama, siswa memahami perintah soal secara keseluruhan hanya saja terdapat kesalahan konsep dalam menentukan keliling dari bangun datar yang terdapat pada gambar. Selain itu siswa tidak mampu membuat model matematika yang sesuai berdasarkan cerita. Untuk selanjutnya, peneliti akan memaparkan hasil analisis jawaban siswa berdasarkan indikator Polya. 


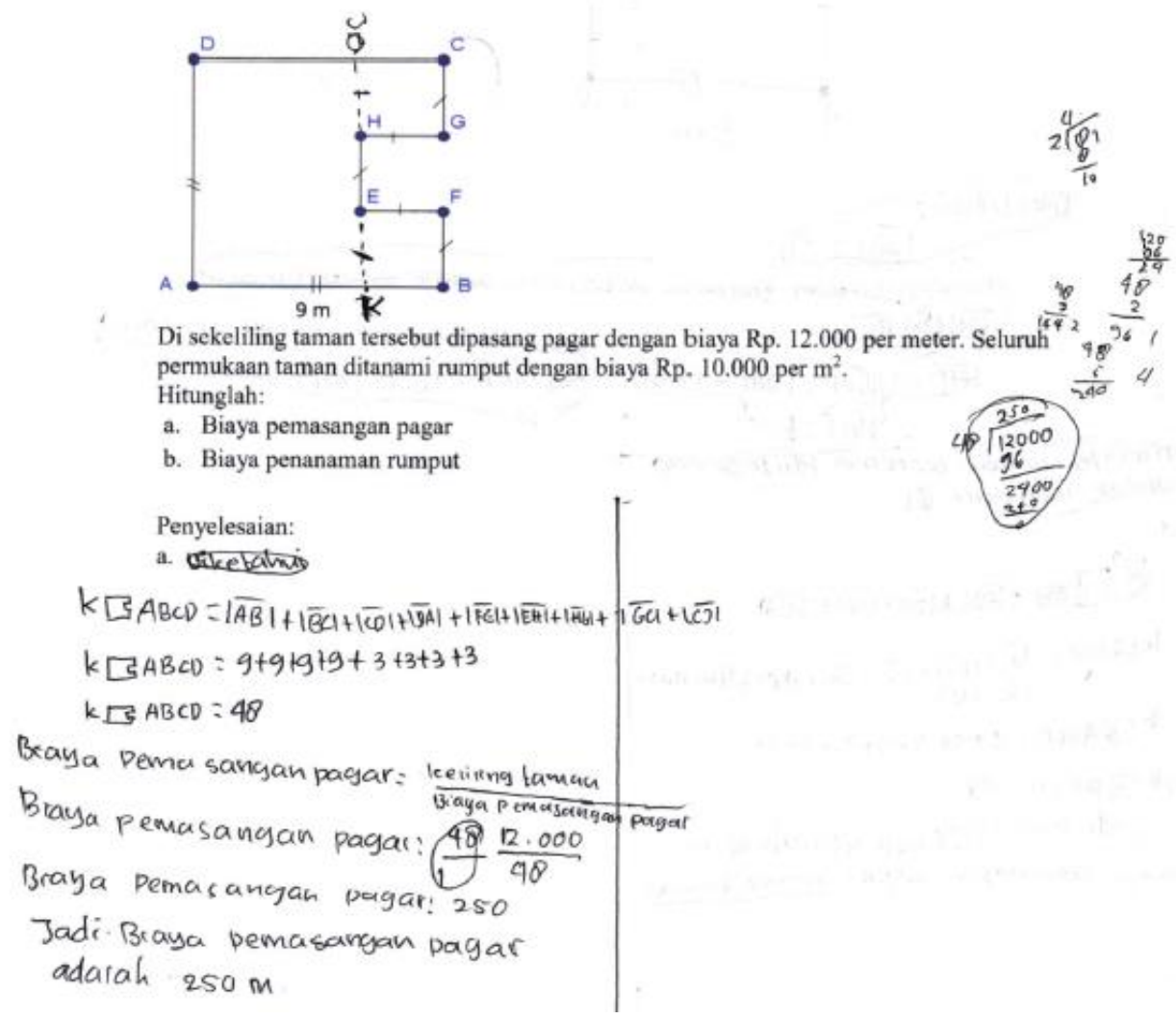

Gambar 1.2 Analisis Jawaban Pertama

Berdasarkan hasil pada gambar 1.2 menunjukkan bahwa siswa ini memenuhi beberapa indikator kemampuan pemecahan masalah dalam Polya. Dari langkah-langkah penyelesaian yang dituliskan terlihat bahwa siswa membaca dan memahami soal tersebut dengan menuliskan unsurunsur diketahui, ditanya dan kecukupan unsur yang diperlukan. Hal itu terlihat dari siswa membuat partisi gambar dengan menarik garis bantu yang sejajar dengan panjang $\overline{A D}$. Dari gambar terlihat bahwa terdapat sebuah persegi panjang dan 2 buah persegi yang memiliki ukuran yang sama. Siswa memahami maksud dari soal sehingga dia mulai berpikir untuk menentukan keliling dari taman terlebih dahulu karena untuk menentukan biaya pemasangan pagar maka terlebih dahulunya dicari keliling dari taman tersebut. Selanjutnya siswa menyusun rencana untuk menyelesaikan latihan tersebut dengan menggali informasi yang terdapat dari cerita. Berdasarkan langkah penyelesian siswa dalam menentukan keliling dari bangun datar terlihat bahwa siswa ini benar dalam menentukan ukuran panjang sisi dari gambar. Namun terdapat kesalahan konsep dalam menentukan keliling dari taman. Hal itu terlihat dari siswa salah menjumlahkan ukuran panjang sisi yang termasuk keliling dari taman ibu Elisa.

Siswa ini memenuhi indikator ketiga yakni melaksanakan rencana. Setelah memikirkan rencana untuk menyelesaikan latihan ini yakni menghitung keliling terlebih dahulu kemudian selanjutnya menentukan biaya yang dibutuhkan untuk membayar pemasangan pagar. Siswa ini tidak memenuhi indikator keempat yakni ia tidak melihat kembali langkah penyelesaian baik pada menghitung keliling dari taman maupun menentukan biaya yang dibutuhkan untuk memasang pagar. Kesalahan umumnya terdapat pada siswa kurang memahami konsep dari keliling suatu bangun datar dan menentukan biaya untuk memasang pagar. Kesalahan lainya muncul ketika siswa menggunakan rumus yang tidak sesuai dengan perhitungan atau bentuk perhitungan yang tidak sesuai dengan rumus. Peneliti menyadari bahwa saat siswa menyelesaikan latihan ini peneliti tidak meminta siswa untuk melihat kembali jawabannya. 
Berdasarkan hasil analisis kemampuan pemecahan masalah menurut indikator Polya, siswa ini memenuhi 3 indikator yakni memahami masalah, membuat rencana penyelesaian masalah dan melaksanakan renacana. Namun konsep yang dipahami kurang ataupun keliru.

2. Jenis Jawaban Kedua

Jenis jawaban kedua menjelaskan bahwa siswa tersebut memahami masalah yang diberikan namun terdapat kesalahan dalam mengartikan gambar dan hasil perhitungan.

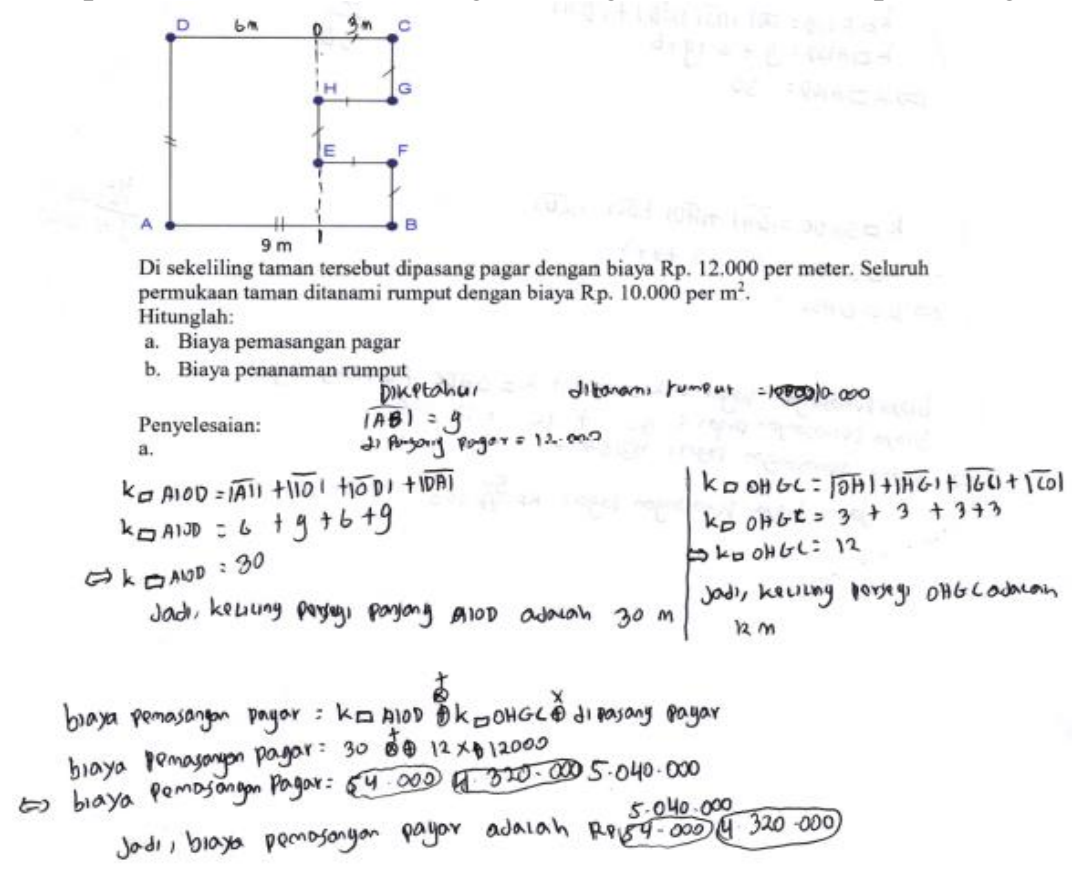

\section{Gambar 1.3 Analisis Jawaban Siswa Kedua}

Berdasarkan hasil pada gambar 1.3 menunjukkan bahwa siswa ini memenuhi indikator pertama yakni memahami masalah dengan menuliskan unsur-unsur diketahui, ditanya dan kecukupan unsur yang diperlukan. Siswa mencoba untuk membuat partisi gambar dengan menarik garis bantu yang sejajar dengan panjang $\overline{A D}$ dan menghitung panjang sisi $\overline{A O}$. Dari gambar terlihat bahwa terdapat sebuah persegi panjang dengan ukuran panjang, lebar yakni $6 \mathrm{~m}$ dan $9 \mathrm{~m}$. Terdapat 2 buah persegi yang memiliki ukuran yang sama. Siswa memahami maksud dari soal sehingga dia mulai berpikir untuk menentukan keliling dari taman terlebih dahulu karena untuk menentukan biaya pemasangan pagar maka terlebih dahulunya dicari keliling dari taman tersebut. Selanjutnya siswa menyusun rencana untuk menyelesaikan latihan dengan menentukan keliling persegi panjang terlebih dahulu lalu kemudian ia menghitung keliling dari persegi yang kecil. Berdasarkan langkah penyelesaian siswa dalam menentukan keliling dari bangun datar terlihat bahwa siswa ini benar dalam menentukan ukuran panjang sisi dari gambar. Namun terdapat kesalahan konsep dalam menentukan keliling dari taman. Hal itu terlihat dari siswa salah menjumlahkan ukuran panjang sisi yang termasuk keliling dari taman ibu Elisa.

Siswa ini memenuhi indikator ketiga yakni melaksanakan rencana. Setelah memikirkan rencana untuk menyelesaikan latihan ini yakni menghitung keliling terlebih dahulu kemudian selanjutnya menentukan biaya yang dibutuhkan untuk membayar pemasangan pagar.Namun siswa ini salah memahami konsep dari keliling suatu bangun datar dan rumus yang digunakan untuk menentukan biaya pemasangan pagar yang tidak sesuai. Siswa ini memenuhi indikator keempat yakni ia melihat kembali langkah penyelesaian pada menentukan biaya yang dibutuhkan untuk memasang pagar. Berdasarkan rumus yang dibuat, ia menyadari bahwa jika dalam 
perhitungan terdapat 2 tanda operasi perkalian dan penjumlahan maka ia terlebih dahulu menghitung perkalian kemudian menjumlahkan hasilnya. Berdasarkan hasil analisis menggunakan indikator Polya, siswa ini memenuhi keempat indikator dari Polya hanya saja siswa ini salah dalam konsep menentukan keliling dari suatu bangun datar.

3. Jenis Jawaban Ketiga

Jenis jawaban yang ketiga menunjukkan bahwa siswa memahami masalah yang diberikan dan menjelaskan jawabannya dengan sangat rinci dan benar.

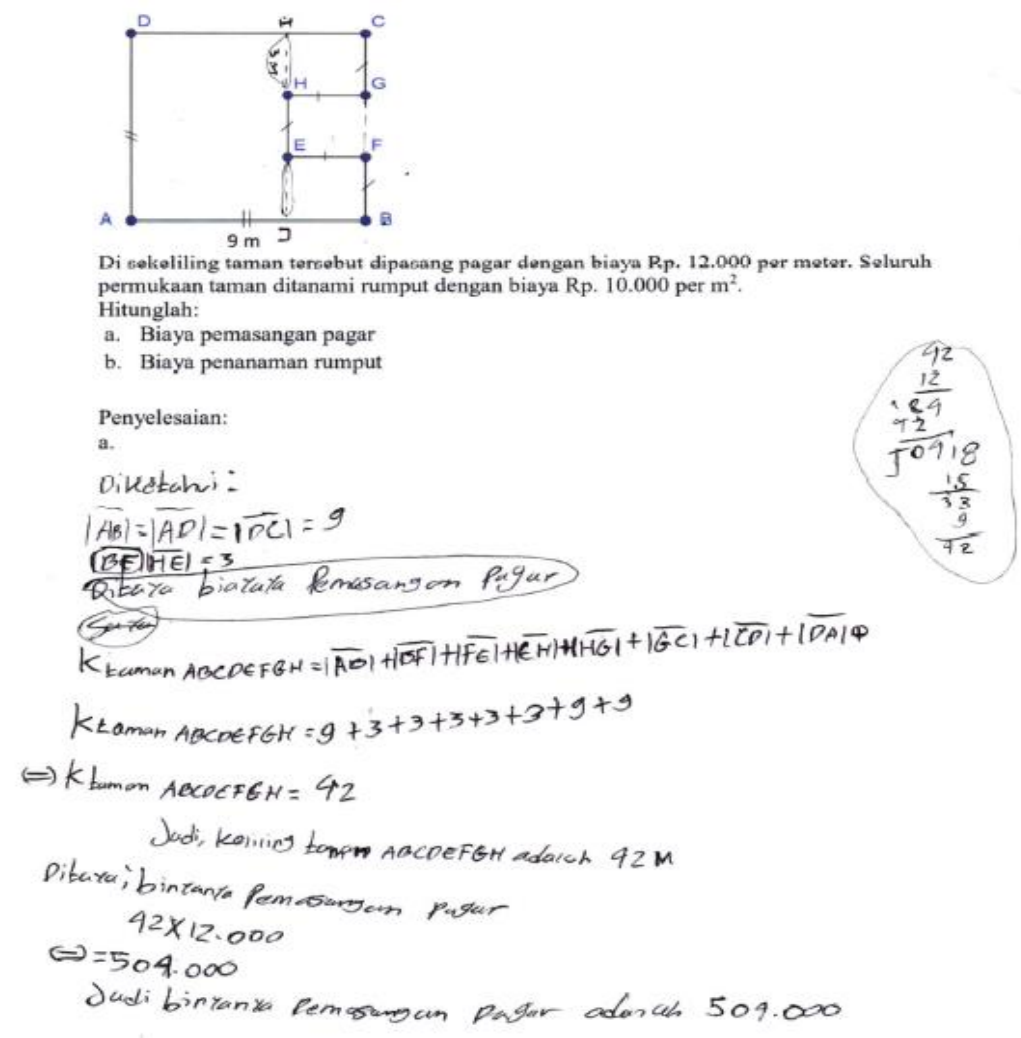

Gambar 1.4 Analisis Jawaban Siswa Ketiga

Berdasarkan hasil pada gambar 1.4 menunjukkan bahwa siswa ini memenuhi keempat indikator dari Polya. Siswa ini memahami maksud dari soal tersebut dengan menuliskan unsurunsur diketahui, ditanya dan kecukupan unsur yang diperlukan. Selanjutnya siswa merencanakan untuk menyelesaikan rencana dengan membuat bangun datar itu menjadi beberapa bagian. Berdasarkan gambar yang dipartisi oleh siswaterdapat sebuah persegi panjang dan 2 buah persegi yang memiliki ukuran yang sama. Selanjutnya siswa berpikir untuk menyelesaikan latihan dengan menentukan keliling dari taman terlebih dahulu karena untuk menentukan biaya pemasangan pagar maka terlebih dahulunya dicari keliling dari taman tersebut. Berdasarkan langkah penyelesian siswa dalam menentukan keliling dari bangun datar terlihat bahwa siswa ini benar dalam menentukan ukuran panjang sisi dari gambar dan ia memahmi konsep dalam menentukan keliling dari taman. Hal itu terlihat dari siswa benar saat menjumlahkan ukuran panjang sisi yang termasuk keliling dari taman ibu Elisa. Setelah memikirkan rencana untuk menyelesaikan latihan ini yaknimenghitungkeliling terlebih dahulu kemudian selanjutnya menentukan biaya yang dibutuhkan untuk membayar pemasangan pagar.

Siswa ini tidak memenuhi indikator keempat yakni ia tidak melihat kembali langkah penyelesaian baik pada menghitung keliling dari taman maupun menentukan biaya yang 
dibutuhkan untuk memasang pagar. Kesalahan umumnya terdapat pada siswa kurang memahami konsep dari keliling suatu bangun datar dan menentukan biaya untuk memasang pagar. Kesalahan lainya muncul ketika siswa menggunakan rumus yang tidak sesuai dengan perhitungan atau bentuk perhitungan yang tidak sesuai dengan rumus. Peneliti menyadari bahwa saat siswa menyelesaikan latihan ini peneliti tidak meminta siswa untuk melihat kembali jawabannya.Berdasarkan hasil analisis kemampuan pemecahan masalah menurut indikator Polya, siswa ini memenuhi keempat indikator dari Polya yakni memahami masalah, membuat rencana penyelesaian masalah dan melaksanakan rencana. Hanya saja siswa ini tidak melihat kembali jawabannya dimana terdapat 2 tanda matematika yang berdekatan yakni tanda ekuivalan dan tanda sama dengan $(=)$

\section{B. Analisis kemampuan pemecahan masalah siswa untuk soal bagian b.}

Pada soal 1 bagian $b$ hanya terdapat dua jenis jawaban yang berbeda. Untuk jawaban yang pertama siswa memahami latihan yang diberikan namun siswa tersebut tidak memahami luas lahan yang dimiliki Ibu Elisa berdasarkan gambar. Untuk jenis jawaban yang kedua siswa memahami semua masalah yang terdapat pada perintah soal dan mampu menjelaskan jawabannya dengan rinci dan benar.

1. Jenis Jawaban Pertama

Pada Jawaban jenis pertama, siswa ini memahami masalah yang diberikan yakni menentukan luas dari taman namun siswa ini tidak mampu mengartikan gambar yang merupakan taman Ibu Elisa.

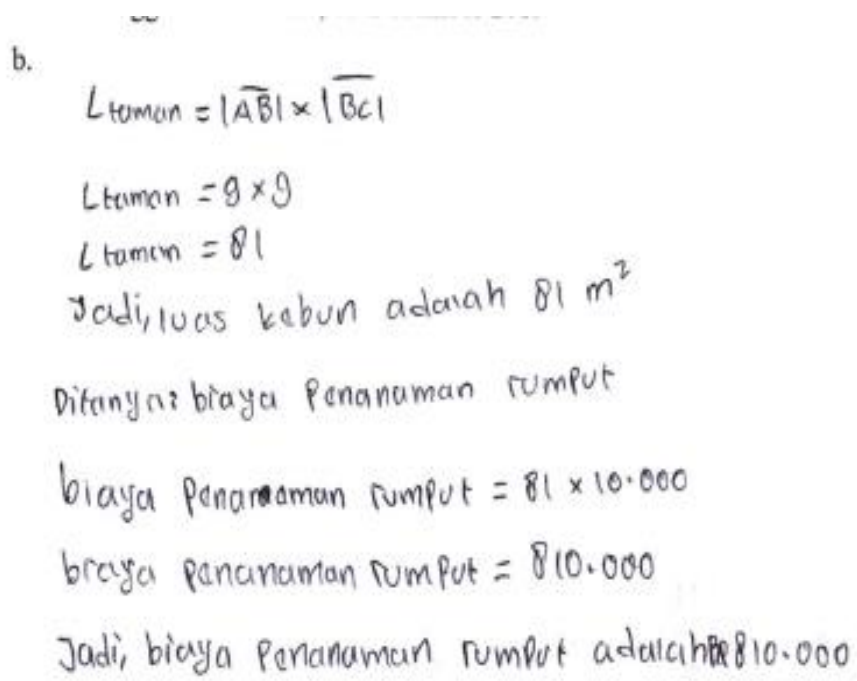

\section{Gambar 2.1 Analisis Jawaban Siswa Pertama}

Berdasarkan hasil pada gambar 2.1 menunjukkan bahwa siswa ini memenuhi keempat indikator dari Polya. Siswa ini memahami maksud dari perintah soal tersebut. Walaupun dalam bentuk penulisan tidak terlihat bahwa siswa menuliskan diketahui maupun ditanyakan namun berdasarkan langkah penyelesaian dapat menjelaskan bahwa untuk menentukan biaya yang digunakan untuk menanam rumput maka terlebih dahulu siswa mencari luas dari taman karena rumput biasanya ditanam di dalam taman.

Selanjutnya siswa merencanakan untuk menyelesaikan latihan tersebut dengan mengitung luas terlebih dahulu kemudian menghitung biaya penanaman rumput. Setelah memikirkan rencana siswa melaksanakan rencana. Berdasarkan langkah penyelesaian siswa dalam 
menentukan luas dari bangun datar terlihat bahwa siswa ini benar dalam menentukan ukuran panjang sisi dari gambar dan ia memahami konsep dalam menentukan luas dari taman. Hanya siswa ini tidak teliti dalam membaca gambar karena jika kita menarik garis putus-putus dari titik sudut $\mathrm{F}$ dan $\mathrm{G}$ maka akan terlihat sebuah persegi kecil yang bukan merupakan luas dari taman.Kesalahan umumnya terdapat pada siswa kurang memahami konsep dari luas suatu bangun datar. Indikatr keempat terlihat dari siswa membuat kesimpulan dari jawabannya.

Berdasarkan hasil analisis kemampuan pemecahan masalah menurut indikator Polya, siswa ini memenuhi keempat indikator dari Polya yakni memahami masalah, membuat rencana penyelesaian masalah, melaksanakan rencana dan melihat kembali.

2. Jenis Jawaban Kedua

Pada jawaban jenis kedua, siswa memahami masalah yang diberikan, siswa memahami gambar dan mampu menjelaskan latihan secara lebih rinci melalui kalimat.

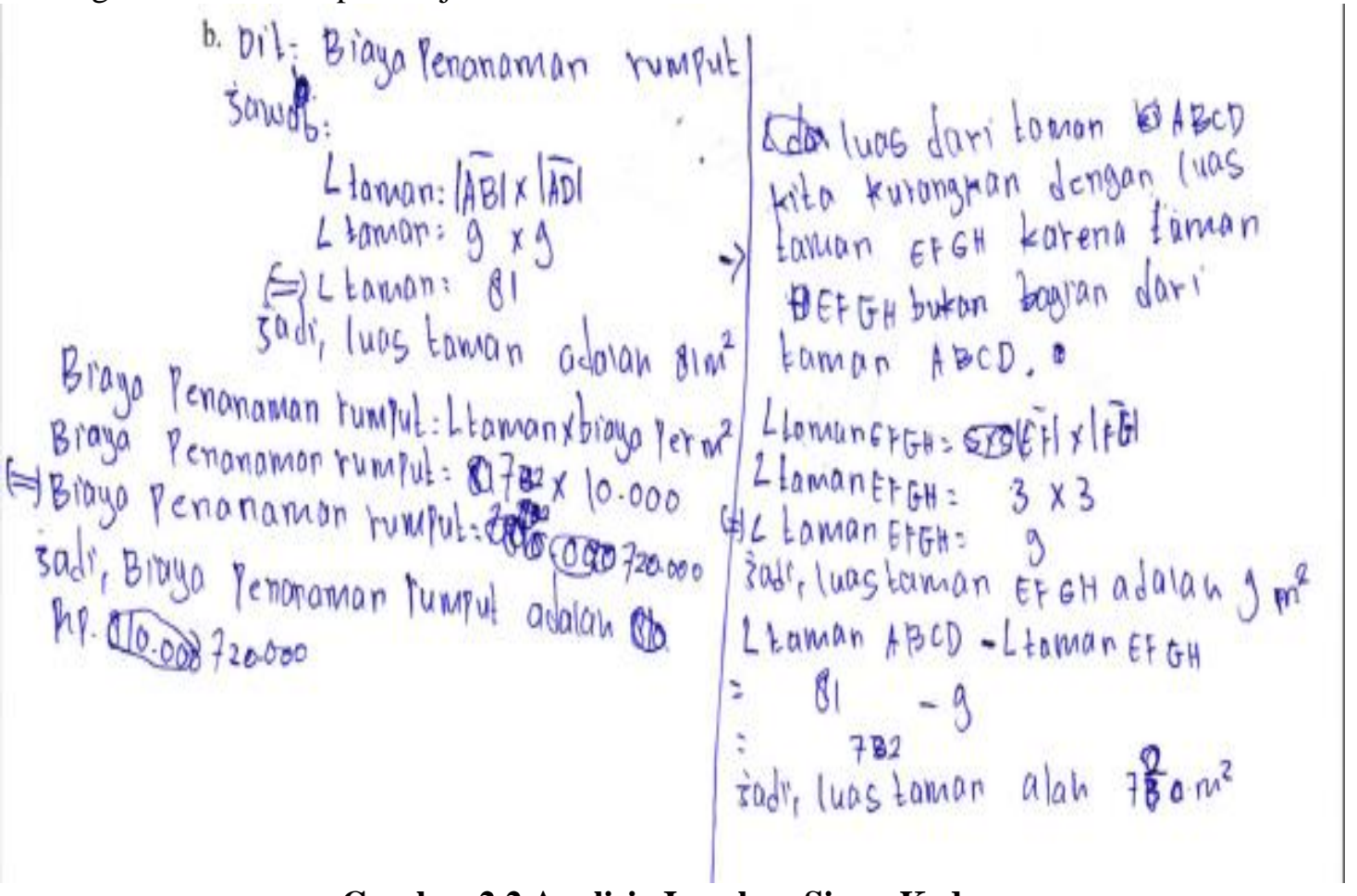

\section{Gambar 2.2 Analisis Jawaban Siswa Kedua}

Berdasarkan hasil pada gambar 2.2 menunjukan bahwa siswa ini memenuhi keempat indikator dari Polya. Siswa ini memahami maksud dari perintah soal. Hal ini ditunjukan dengan siswa menuliskan unsur yang ditanyakan. Selanjutnya siswa merencanakan untuk menyelesaikan latihan tersebut dengan mengitung luas taman secara keseluruhan kemudian ia menghitung luas taman yang kecil. Ia memahami bahwa luas daerah persegi yang kecil bukan termasuk dalam luas taman. Maka ia harus mengurangkan luas taman yang besar dengan yang kecil. Selanjutnya ia menghitung biaya penanaman rumput. Berdasarkan langkah penyelesaian yang dibuat oleh siswa dapat menjelaskan bahwa untuk menentukan biaya yang digunakan untuk menanam rumput maka terlebih dahulu siswa mencari luas dari taman karena rumput biasanya ditanam di dalam taman. Setelah memikirkan rencana siswa melaksanakan rencana. Berdasarkan langkah penyelesaian siswa dalam menentukan luas dari bangun datar terlihat bahwa siswa ini benar dalam menentukan ukuran panjang sisi dari gambar dan ia memahami konsep dalam menentukan luas dari taman. Indikatr keempat terlihat dari siswa membuat kesimpulan dari jawabannya. 
Berdasarkan hasil analisis kemampuan pemecahan masalah menurut indikator Polya, siswa ini memenuhi keempat indikator dari Polya yakni memahami masalah, membuat rencana penyelesaian masalah, melaksanakan rencana dan melihat kembali.

\section{SIMPULAN DAN SARAN}

\section{KESIMPULAN}

Berdasarkan hasil analisis dan pembahasan dengan menggunakan langkah-langkah dari Polya maka dapat disimpulkan bahwa penerapan model Problem Based Learning (PBL) dapat meningkatkan kemampuan pemecahan masalah siswa pada materi persegi dan persegi panjang di Kelas VIII SMPK St. Paulus Karuni. Hal itu dapat dilihat ketika siswa menyelesaikan suatu latihan yang berkaitan dengan masalah kontekstual siswa mampu mengaitkan masalah nyata dengan materi yang dipelajari siswa di kelas. Latihan yang diberikan mampu mendorong siswa untuk menemukan sendiri solusi dari permasalahannya. Siswa pada umumnya mengerti atau memahami perintah dari soal yaitu apa yang diketahui dan syarat khusus yang terdapat dalam soal, siswa mampu membuat perencanaan untuk menyelesaikan masalah tersebut hal itu dapat dilihat ketika siswa mencoba untuk mengingat kembali rumus atau definisi yang pernah dia pelajari, siswa mampu menjalankan perencanaan yang dibuat hal itu dapat dilihat ketika siswa memberikan jawabannya, dan siswa mampu memantau kembali jawabannya. Hal itu dapat dilihat ketika siswa memberikan kesimpulan akhir dari jawabannya.

Dari hasil jawaban yang diberikan siswa, terlihat beberapa siswa yang masih belum memahami konsep untuk menentukan keliling dan luas dari bangun datar persegi dan persegi panjang. Peneliti menyadari bahwa dalam menyelesaikan latihan peneliti kurang melakukan penyelidikan terhadap masingmasing siswa sehingga banyak siswa mengalami kesulitan dalam menentukan keliling maupun luas dari bangun taman.

\section{SARAN}

Penerapan model pembelajaran berbasis masalah dapat dijadikan salah satu alternatif model pembelajaran bagi guru untuk mengajar materi geometri. Selain itu perlu juga didukung dengan latihan yang sesuai dengan kondisi siswa. Pendampingan baik individu maupun kelompok sangat membantu proses berpikir siswa karena dengan pendampingan guru dapat menggali informasi yang sudah diperoleh siswa. 


\section{Daftar Pustaka}

Ahmad Fauzan, A., Oci Y Sari. (2017). Pengembangan Alur Belajar Pecahan Berbasis Realistic Mathematics Education: Prosiding Seminar Nasional Pascasarjana (SNP) Unsyiah 2017, April 12, 2017, Banda Aceh, Indonesia.

Ahmad Fauzan, Slettenhaar, D. \& Plomp, T. (2002). Traditional Mathematics Education vs.Realistic Mathematics Education: Hoping for Changes. Proceeding of the 3rd Mathematics Education and Society (MES) conference, Helsinghor, Denmark.

As'ari, Abdur Rahman dkk.,( 2017). Buku guru Matematika. Kementrian Pendidikan dan Kebudayaan Republik Indonesia. Jakarta.

George Polya. (1973). "How to Solve It”. Princeton: Princeton University Press. Cetakan ke-2 Gravemeijer, Koeno. Teori Pendidikan Matematika Realistik Sebagai Satu Panduan Untuk Pendidikan Matematika Interaktif Berbasis Masalah (Part 1) (online). http://www.google.com/amp/s/p4mriundikhsa.wordpress.com diakses pada tanggal 25 Maret 2019.

Mulyana, Aina. (2017). Pembelajaran Abad 21 dan Kurikulum 2013 (online). http://ainamulyana.blogspot.com/2017/03/pembelajaran-abad-21-dan-kurikulum-2013.html. diakses pada tanggal 25 Maret 2019

Sukardi. (2003). Metodelogi Penelitian Pendidikan. Yogyakarta: Bumi Aksara

Sugiyono. (2008). Statistik untukPenelitian. Bandung: CVAlfabeta. 